medRxiv preprint doi: https://doi.org/10.1101/2020.09.20.20197616; this version posted September 23, 2020. The copyright holder for this

\title{
Urban versus rural prevalence of intestinal parasites using multi-parallel qPCR in
} Colombia

Patricia E. Bryan ${ }^{1}$, Marcela Romero ${ }^{2}$, Miryan Sánchez ${ }^{2}$, Giovanny Torres ${ }^{2}$, Wilber Gómez ${ }^{2}$, Marcos Restrepo $^{2}$, Alejandro Restrepo ${ }^{1,2} *$, Rojelio Mejia ${ }^{1} *$

1. Laboratory of Human Parasitology, National School of Tropical Medicine, Baylor College of Medicine, Houston, Texas.

2. Instituto Colombiano de Medicina Tropical, Universidad CES, Medellín, Colombia

*Contibuted equally

Corresponding author: Rojelio Mejia,rmejia@bcm.edu

\begin{abstract}
Stool samples from 122 children from urban slum $(n=72)$ and rural $(n=50)$ areas were analyzed using multi-parallel real-time qPCR to determine the prevalence of intestinal parasites from two communities in Colombia. Findings indicated a prevalence of $86.1 \%$ Blastocystis spp., 62.5\% Giardia intestinalis, 19.4\% Cryptosporidium spp., 19.4\% Ascaris lumbricoides, and 5.6\% Trichuris trichiura in an urban slum; and 76\% Blastocystis spp., 68\% Giardia intestinalis, 20\% Entamoeba histolytica, 50\% Ascaris lumbricoides, 46\% Trichuris trichiura and 2\% Strongyloides stercoralis in rural areas. Polyparasitism was higher in rural (58\%) compared to urban $(25 \%)$ areas $(p=0.001)$. Trichuris trichiura burden was higher in the rural area $(p=$ 0.002 ). Over $40 \%$ of helminth infections in rural areas had a heavy parasite burden by WHO classification. Over half of urban and rural children were infected with Giardia intestinalis and Blastocystis spp. Our data provides accurate epidemiologic surveillance for public health interventions.
\end{abstract}


Intestinal parasites are globally widespread infectious organisms disproportionately affecting children in resource-limited areas with associated morbidity that is poorly understood and can have long-term child health implications. Environmental surroundings influence exposure to these parasites, as does the differences in communities. Reliable, highly sensitive and specific diagnostic tests for intestinal parasitic infections are critical for treatment decisions in mass drug administration programs, impact evaluation, and surveillance. ${ }^{1-3}$

A multi-parallel real-time quantitative PCR (qPCR) assay was used to detect intestinal parasites commonly infecting children living in resource-limited areas including soil-transmitted helminths (STH) (Ascaris lumbricoides, Ancylostoma duodenale, Necator americanus, Strongyloides stercoralis, and Trichuris trichiura), protozoa (Cryptosporidium spp., Entamoeba histolytica, and Giardia intestinalis) and heterokont (Blastocystis spp.). Data from Colombia on intestinal parasite prevalence in children is limited, especially among preschool-age children. ${ }^{4,5}$ The study population included preschool and school-age children living in urban slums of the city of Medellín (mean age $=2$ years) and rural areas of the town of Unguía (mean age $=2.5$ years) located in the northwest Andean region of Colombia. Recently, protozoa detected by a molecular approach was reported among school-age children in an urban area of southwest Colombia with a prevalence of 39.2\% Blastocystis spp., $10.6 \%$ G. intestinalis, and $9.8 \%$ Cryptosporidium spp. ${ }^{3}$ Intestinal parasites were previously detected by microscopy among children under 15 years of age in a rural area of the northern coastal region of Colombia with $63 \%$ infected with protozoa and $69 \%$ infected with STH. ${ }^{6}$ In Colombia, studies reporting molecular epidemiologic data on intestinal parasites among children from both urban and rural settings in the same study population are sparse. ${ }^{3,7-9}$ Limited molecular epidemiologic surveillance data on childhood intestinal parasitism in areas with concentrations of poverty undermines positive child health outcomes. ${ }^{3,9}$ Our study contributes to data comparing the prevalence of intestinal parasites detected by qPCR among urban slum and rural children from the study sampling areas in Colombia. Because the interplay between socioeconomic and environmental factors, hygiene, and transmission dynamics contribute to increased child vulnerability to intestinal parasite exposure. ${ }^{10}$ accurate epidemiologic data on both STH and protozoa is critical to decision making for treatment and public health interventions for populations of children in contrasting community settings.

Stool samples were analyzed from 122 Colombian children living in urban slums $(n=72)$ and rural areas $(\mathrm{n}=50)$. Parasite DNA was extracted from $50 \mathrm{mg}$ of stool from each stool sample using MP FastDNA ${ }^{\mathrm{TM}}$ for Soil Kit (MP Biochemicals, Solon, $\mathrm{OH}$ ) according to the manufacturer's instructions for all parasites, except Trichuris trichiura, which required an additional heating step. ${ }^{11}$ Species-specific primers and probes for these nine parasites were previously designed and tested demonstrating $100 \%$ sensitivity and specificity. ${ }^{11}$ Calculated $G$. intestinalis cysts and STH eggs were derived from spiked samples with known parasite concentrations. $^{11}$

Overall, intestinal parasites among children in this study were found to be similarly highly prevalent in both urban slum (97.2\%) and rural areas (90\%), with G. intestinalis and Blastocystis spp. predominantly prevalent across these sampling settings. Because urban 
populations generally have better access to sanitation and clean water compared to rural populations, ${ }^{4}$ the high prevalence of intestinal parasites; namely G. intestinalis and Blastocystis spp., in both urban and rural areas $(62.5 \%$ and $86.1 \%$ versus $68 \%$ and $76 \%$, respectively) is noteworthy. Previously reported data from Colombia on urban slum children in Medellín indicated a significantly lower prevalence of giardiasis (25.9\%) detected by microscopy, ${ }^{12}$ and the most recent national survey reported that $15.4 \%$ of Colombian children were infected with $G$. intestinalis and $57.7 \%$ were infected with Blastocystis spp. also detected by microscopy-based diagnostic methods. ${ }^{13}$ Despite the high prevalence of Blastocystis spp., the clinical importance of this parasite remains unclear. ${ }^{14}$ However, this parasite is an important indicator of fecal contamination of food and water. ${ }^{14} \mathrm{G}$. intestinalis represents a significant public health problem worldwide. ${ }^{3,5}$ Giardiasis can cause acute or chronic diarrhea but is often asymptomatic and is associated with detrimental impacts to growth and development in children. ${ }^{5,14}$ In the present study, G. intestinalis spiking studies were also conducted, from which cysts per gram of stool were calculated. Subsequently, similar $G$. intestinalis infection burden was found among urban slum and rural children (Figure 1), suggesting exposure to similar risk factors for giardiasis in both settings. Because fecal contamination of drinking water is the most common source of $G$. intestinalis cysts from domestic animal and human origins, 5,14 the inadequate or lack of access to clean water typically found in resource-deprived urban slum and rural areas of developing countries may explain the prevalence and parasite burden in the study population.

In this study, helminthiasis was more prevalent among rural children compared to the urban study population. The most prevalent STH, A. lumbricoides and T. trichiura, were significantly higher among rural children comparably (50\% and $46 \%$ versus $19.4 \%$ and $5.6 \%$, respectively). This was not unexpected due to similar transmission dynamics and greater risk of exposure to contaminated soil in rural settings combined with poor hygiene awareness and handto-mouth behavior characteristic of early childhood ${ }^{10}$ To evaluate STH parasite burden, DNA $\mathrm{fg} / \mu \mathrm{L}$ was correlated with eggs per gram (epg) of stool-based on WHO threshold criteria for the classification of parasite burden for A. lumbricoides (1 - 5,000 light; > 5,000 - 50,000 moderate; and > 50,000 heavy); T. trichiura ( 1 - 999 light; 1,000 - 9,999 moderate; $\geq 10,000$ heavy; and for hookworm ( 1 - 1,999 light; 2,000 - 3,999 moderate; $\geq 4,000$ heavy). ${ }^{15}$ Over $40 \%$ of STH infections among children in the rural setting were classified as having a heavy parasite burden. Among rural children with trichuriasis, parasite burden was higher (9,953 epg) compared to those in urban slums (325 epg) $(\mathrm{p}=0.002)$ (Figure 2). Polyparasitism was also found in the overall study population, with the highest prevalence found among rural children $(58 \%)$ compared to children in urban slum areas $(25 \%)(p=0.001)$. Because morbidity is proportional to parasite burden, ${ }^{2,9}$ polyparasitism in the study population is a significant concern given the young age of these children. This young age group is at increased vulnerability to the detrimental health impacts of intestinal parasites due to critical stages of growth and development occurring during early childhood. ${ }^{16}$ Moreover, polyparasitism involving both STH and protozoa serves as an important indicator of inadequate sanitary conditions and continual reinfection. ${ }^{9}$

Findings from this study suggest that children from urban slums of Medellín and rural areas of Unguía in Colombia live in highly contaminated environments with continuous exposure to intestinal parasites in these different communities. The peripheral neighborhoods of the urban 
poor in cities such as Medellín, Colombia, typically have informal housing development with poor housing standards, overcrowding, and inadequate infrastructure for sanitation and access to clean water. ${ }^{17-19}$ These conditions are comparable to resource-deprived rural settings and can often lead to even greater exposure to fecal contamination in households, schools, and where urban slum children play and spend most of their time. ${ }^{13}$ The predominance of G. intestinalis in both urban slum and rural areas suggests the likelihood of exposure to similar contamination sources in geographically contrasting communities. ${ }^{17}$ The high prevalence of intestinal parasites found in the study population confirms that childhood intestinal parasitic infections are a relevant health issue in both urban poor and rural communities in Colombia and serves as an important indicator of community-level socioeconomic development. ${ }^{8,10}$ Because accurate prevalence data in a region or community is essential for identifying local vulnerabilities, ${ }^{4,17,19}$ molecular epidemiologic data from this study provides evidence of important community needs common to both urban slum and rural communities included in this study. Accurate epidemiologic data from this study is also critical for treatment decisions in mass drug administration programs, impact evaluation, and surveillance. This is particularly important given that treatment programs for intestinal parasites in Colombia are not aimed at the preschool-age population and do not include treatment for intestinal protozoa. ${ }^{4,5}$ Moreover, prevalence data generated from this study provides evidence for local decision making for implementing resources to improve living conditions for urban and rural populations of children in Colombia. ${ }^{14,19}$ A major limitation of this study was the lack of $G$. intestinalis assemblages and Blastocystis subtype identification. Future studies will include the assemblage and subtyping to allow correlation to human disease. 
medRxiv preprint doi: https://doi.org/10.1101/2020.09.20.20197616; this version posted September 23, 2020. The copyright holder for this

\section{References}

1. Nikolay, B., Brooker, S. J. \& Pullan, R. L. (2014). Sensitivity of diagnostic tests for human soil-transmitted helminth infections: a meta-analysis in the absence of a true gold standard. International Journal for Parasitology, 44(11), 765-774. https://doi.org/10.1016/j.ijpara.2014.05.009

2. Dunn, J. C., Papaiakovou, M., Han, K. T., Chooneea, D., Bettis, A. A., Wyine, N. Y., Lwin, A. M. M., Maung, N. S., Misra, R., Littlewood, D. T. J. \& Anderson, R. M. (2020). Parasites \& Vectors, 12(324). https://doi.org/10.1186/s13071-020-04197-w

3. Villamizar, X., Higuera, A., Herrera, G., Vasquez-A, L. R., Buitron, L., Muñoz, L. M., Gonzales-C, F. E., Lopez, M. C., Giraldo, J. C. \& Ramírez, J. D. (2019). Molecular and descriptive epidemiology of intestinal protozoan parasites of children and their pets in Cauca, Colombia: a cross-sectional study. BMC Infectious Diseases, 19(190).

https://doi.org/10.1186/s12879-019-3810-0

4. Bouwmans, M. C. H., Gaona, M. A., Chenault, M. N., Zuluaga, C. and Pinzón-Rondon, Á, M. (2016). Prevalence of intestinal parasitic infections in preschool-children from vulnerable neighborhoods in Bogotá. Revista de la Universidad Industrial de Santander, Salud, 48, 2, 178187. https://doi.org/10.18273/revsal.v48n2-2016002

5. García-Montoya, G. M. and Botero-Garces, J. H. (2018). Giardiasis in Colombia: a review of the current knowledge. Current Tropical Medicine Reports, 5, 3, 154-161.

https://doi.org/10.1007/s40475-018-0152-8

6. Carmona-Fonseca, J. \& Botero, A. M. C. (2014). Understanding the social determinants of health/disease: intestinal parasites and malnutrition in the families of Urabá, Colombia. Social Medicine, 8, 2, 56-67.

7. Salcedo-Cifuentes, M., Florez, O., Bermúdez, A., Hernández, L., Araujo, C. \& Bolaños, M. V. (2012). Intestinal parasitism prevalence amongst children from six indigenous communities residing in Cali, Colombia. Rev Salud Pública, 14, 1, 156-168. https://doi.org/10.1590/s012400642012000100013

8. Carmona-Fonseca, J. \& Flórez, E. M. A. (2017). Intestinal parasites and "progress": a case study from Urabá Antioquia (Colombia). Social Medicine, 11, 2, 35-50.

9. Higuera, A., Villamizar, X., Herrera, G., Giraldo, J. C., Vasquez-A., L. R., Urbano, P., Villalobos, O., Tovar, C. \& Ramírez, J. D. (2020). Molecular detection and genotyping of intestinal protozoa from different biogeographical regions of Colombia. PeerJ, 8, e8554. https://doi.org/10.7717/peerj.8554

10. Rivero, M. R., De Angelo, C., Nuñez, P., Salas, M., Motta, C. E., Chiaretta, A., Salamón, O. D. \& Liang, S. (2017). Environmental and socio-demographic individual, family and neighborhood factors associated with children intestinal parasitosis at Iguazú, in the subtropical northern border of Argentina. PLOS Negl Trop Dis 11(11), e0006098.

https://doi.org/10.1371/journal.pntd.0006098 
medRxiv preprint doi: https://doi.org/10.1101/2020.09.20.20197616; this version posted September 23, 2020. The copyright holder for this preprint (which was not certified by peer review) is the author/funder, who has granted medRxiv a license to display the preprint in perpetuity.

11. Mejia, R., Vicuna, Y., Broncano, N., Sandoval, C., Vaca, M., Chico, M., Cooper, P. J., Nutman, T. B. (2013). A novel, multi-parallel, real-time polymerase chain reaction approach for eight gastrointestinal parasites provides improved diagnostic capabilities to resource-limited atrisk populations. American Journal of Tropical Medicine and Hygiene, 88, 1041-1047. https://doi.org/10.4269/ajtmh.12-0726

12. Lozano, A. M, Montoya, G. G., Díaz, A. L. G. \& Garces, J. B. (2009). Prevalencia de parásitos intestinales en niños que asisten al Templo Comedor Sagrado Corazón Teresa Benedicta de la Cruz, del barrio Vallejuelos, Medellín, 2007. IATREIA, 22, 3, 227-234. ISSN 0121-0793

13. Ministerio de Salud y Protección Social, Universidad de Antioquia. (2015). Encuestra nacional de parasitismo intestinal en población escolar 2012-2014. Medellín: Facultad Nacional Salud Pública, Universidad de Antioquia. https://www.minsalud.gov.co/sites/rid/Lists/BibliotecaDigital/RIDE/VS/PP/ET/encuestanacional-de-parasitismo-2012-2014.pdf

14. Hernández, P. C., Morales, L., Chaparro-Olaya, J., Sarmiento, D., Jaramillo, J. F., Ordoñez, G. A., Cortés, F. \& Sánchez, L. K. (2019). Intestinal parasitic infections and associated factors in children of three rural schools in Colombia: A cross-sectional study. PLOS ONE, 14(7), Article e0218681. https://doi.org/10.1371/journal.pone.0218681

15. World Health Organization. (2002). Prevention and control of schistosomiasis and soil transmitted helminthiasis: WHO technical report series $\mathrm{N}^{\circ} 912$. Report of a WHO expert committee. https://www.who.int/intestinal_worms/resources/who_trs_912/en/

16. Harhay, M. O., Horton, J. \& Olliaro, P. L. (2010). Epidemiology and control of human gastrointestinal parasites in children. Expert Rev Anti Infect Ther, 8(2), 219-234.

https://doi.org/10.1586/eri.09.119

17. Valencia, S. (2016). Socio-environmental vulnerabilities in formal and informal peri-urban Bogotá and Soacha, Colombia [Doctoral dissertation, Lund University]. Lund University Digital Archive. https://portal.research.lu.se/portal/en/publications/caught-between-spaces(1ed39250a1d9-49aa-86fb-865f24bf18d7).html

18. Ajeagah, G., Wouafo, M., Ezenguele, G. \& Nzukam, J. (2013). Presence of gastrointestinal parasites in a tropical urban region (Yaoundé, Cameroon). Comparative Parasitology, 80(2), 279283. https://doi.org/10.1654/4607.1

19. Lucci, P., Bhatkal, T., Khan, A. \& Berliner, T. (2015). What works in improving the living conditions of slum dwellers: a review of the evidence across four programmes. ODI. Overseas Development Institute, Development Progress. https://www.odi.org/publications/10222-whatworks-improving-living-conditions-slum-dwellers-review-evidence-across-four-programmes 
medRxiv preprint doi: https://doi.org/10.1101/2020.09.20.20197616; this version posted September 23, 2020. The copyright holder for this preprint (which was not certified by peer review) is the author/funder, who has granted medRxiv a license to display the preprint in perpetuity. All rights reserved. No reuse allowed without permission.

\section{Figure 1}

Estimated Giardia intestinalis cysts among children in urban (Medellín) compared to rural area (Unguía) had similar burden of infection.

Figure 2

Estimated helminth burden in eggs per gram of stool using qPCR among children in urban (Medellín) compared to rural areas (Unguía) had equal Ascaris but higher Trichuris burden of infection in rural areas. 
Table 1. Urban (Medellín) and rural (Unguía) parasite prevalence and infection burden in DNA $\mathrm{fg} / \mu \mathrm{L}$.

\begin{tabular}{|c|c|c|c|c|c|c|}
\hline Parasite species & $\begin{array}{c}\text { Urban } \\
\text { (Medellin) } \\
n=72\end{array}$ & $\begin{array}{l}\text { Rural } \\
\text { (Unguía) } \\
\mathrm{n}=50\end{array}$ & P-value & $\begin{array}{l}\text { Urban DNA } \\
(\mathrm{fg} / \mu \mathrm{L}) \\
\text { Geomean }\end{array}$ & $\begin{array}{l}\text { Rural DNA } \\
(\mathrm{fg} / \mu \mathrm{L}) \\
\text { Geomean }\end{array}$ & P-value \\
\hline Any parasite & $70(97.2 \%)$ & $45(90 \%)$ & 0.091 & & & \\
\hline $\begin{array}{l}\text { Ascaris } \\
\text { lumbricoides }\end{array}$ & $14(19.4 \%)$ & $25(50 \%)$ & 0.0004 & 18.20 & 4.764 & 0.478 \\
\hline $\begin{array}{l}\text { Ancylostoma } \\
\text { duodenale }\end{array}$ & 0 & 0 & $*$ & $*$ & $*$ & $*$ \\
\hline $\begin{array}{l}\text { Necator } \\
\text { americanus }\end{array}$ & 0 & 0 & $*$ & $*$ & $*$ & $*$ \\
\hline $\begin{array}{l}\text { Strongyloides } \\
\text { stercoralis }\end{array}$ & 0 & $1(2 \%)$ & $*$ & $*$ & 3.122 & $*$ \\
\hline $\begin{array}{l}\text { Trichuris } \\
\text { trichiura }\end{array}$ & $4(5.6 \%)$ & $23(46 \%)$ & 0.0001 & 0.0036 & 0.1090 & 0.002 \\
\hline Blastocystis spp. & $62(86.1 \%)$ & $38(76 \%)$ & 0.155 & 1.042 & 1.880 & 0.873 \\
\hline $\begin{array}{l}\text { Cryptosporidium } \\
\text { spp. }\end{array}$ & $14(19.4 \%)$ & 0 & $*$ & 5.576 & $*$ & $*$ \\
\hline $\begin{array}{l}\text { Entamoeba } \\
\text { histolytica }\end{array}$ & 0 & $10(20 \%)$ & $*$ & $*$ & 2.701 & $*$ \\
\hline $\begin{array}{l}\text { Giardia } \\
\text { intestinalis }\end{array}$ & $45(62.5 \%)$ & $34(68 \%)$ & 0.533 & 4.720 & 0.7736 & 0.114 \\
\hline
\end{tabular}




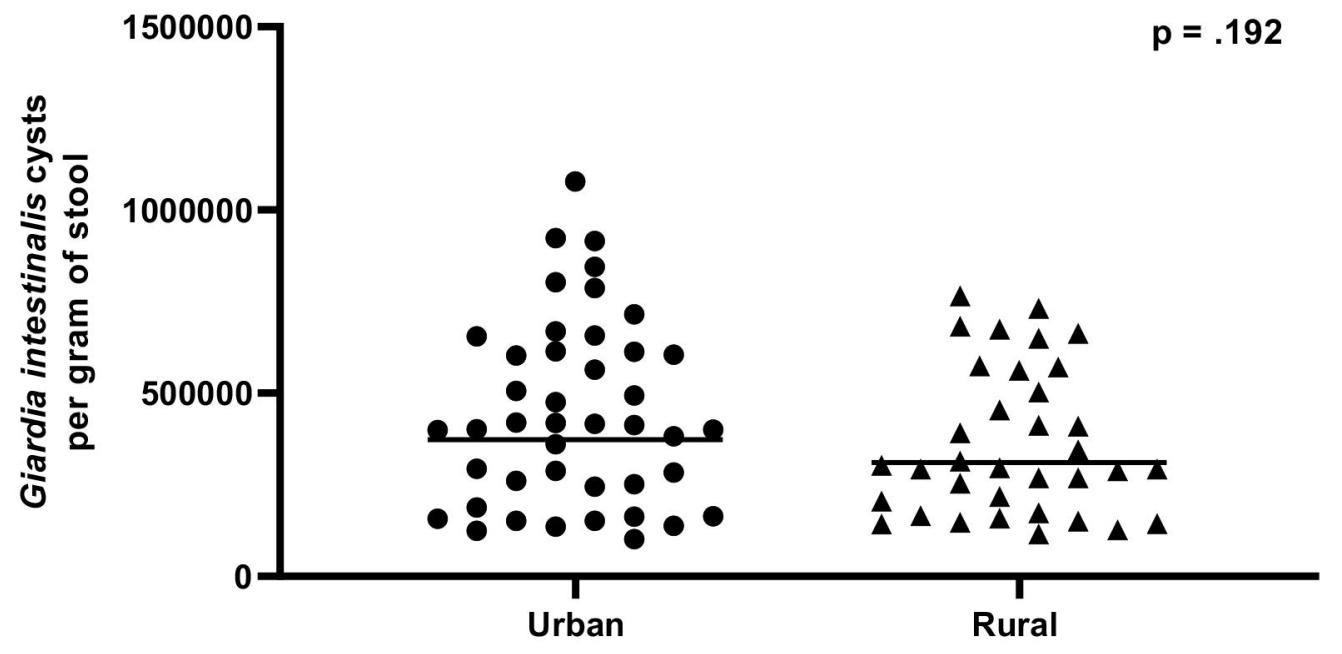




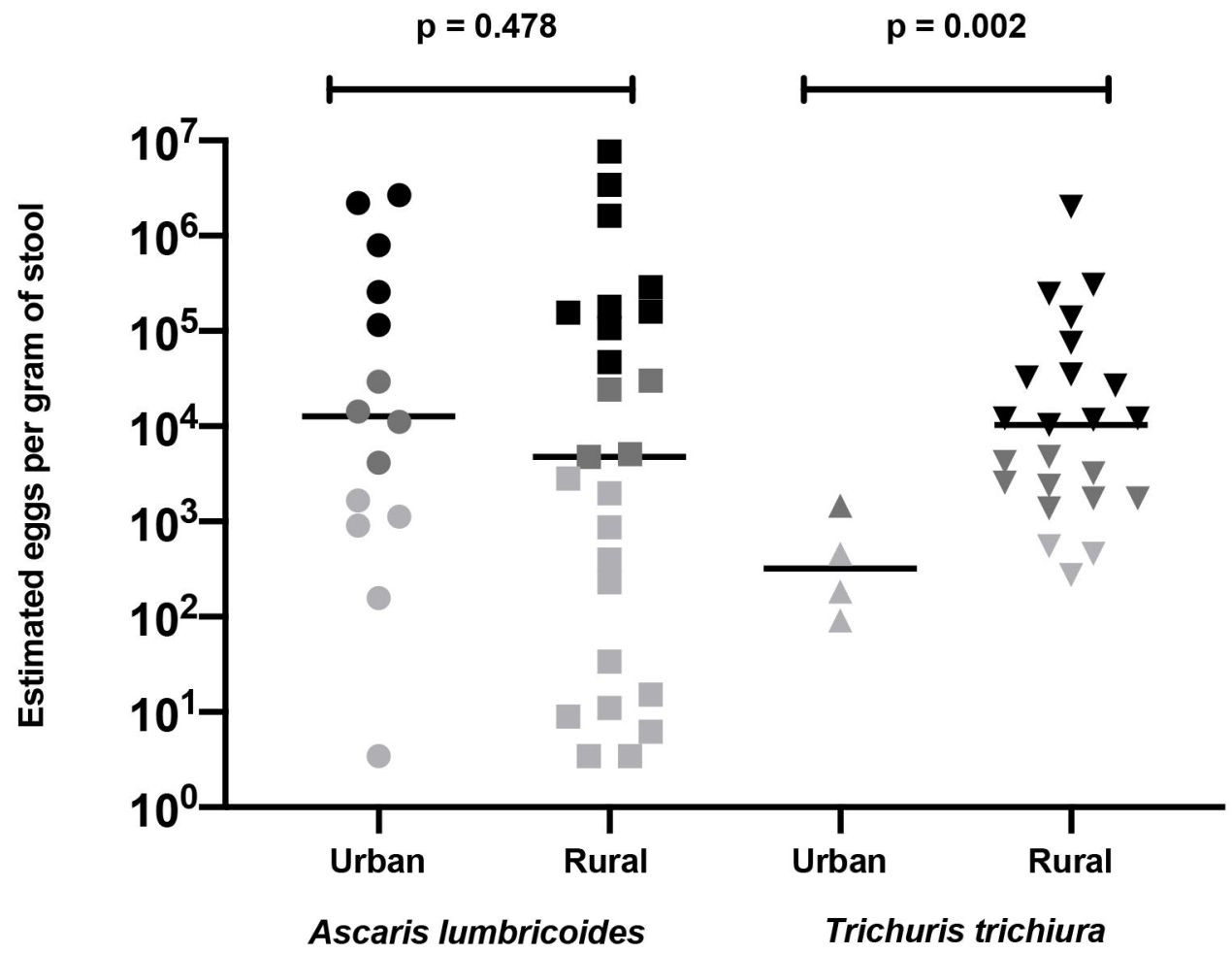

